\title{
The Impacts of PETI on the Batang Hari River to the Decline of Water Quality, Land Transfer Function, Socio-Cultural Life and the Community Economy
}

\author{
* Desrizal, Nasfryzal Carlo, and Nurhasan Syah \\ Master Program of Environmental Science, Universitas Negeri Padang, Indonesia \\ Email: d3s.ical@gmail.com
}

*Corresponding Author, Received: April 18, 2019, Revised: May 15, 2019, Accepted: May 28, 2019

\begin{abstract}
One of the Batang Hari watersheds flows in the Jorong Gasing area of Nagari Lubuk Ulang-Aling, Sangir Batang Hari. In this area, for generations, people use river water for various activities such as irrigating rice fields, transportation facilities, inland fisheries, and toilet washing facilities. But a few years ago there began to be an Unlicensed Gold Mining (PETI) activity. As a result, the condition of the Batang Hari river is alarming, as the level of turbidity is very high, damage to the right-left border of the river, destruction of forest areas, and even affect the social and economic life of the community. Therefore, this research was conducted to describe and prove the full impact of the PETI activity. The results showed a decrease in the quality of Batang Hari Hari river, specifically TSS parameters. The over function land was very significant where land cover in 2000 was 61.22 ha of secondary dryland forest to 25.18 ha in 2017 . There was evidence of changes in socio-economic life with $63 \%$ of the surrounding community no longer utilizing river water, mutual cooperation activities are decreasing, conflicts often occur, as well as an increase in the economy but its growth is unpredictable.
\end{abstract}

Keywords: Gold Mining, River Quality, Land Transfer Function, Social Community

\section{Introduction}

There are around 606 rivers in West Sumatera Province, both large and small, with cross-provincial rivers of 27 large rivers and small rivers that cross the provinces of North Sumatera, Riau, Jambi and Bengkulu. The cross district/city rivers are 81 rivers and rivers in the district/city administrative area are 498 large and small rivers (Bapedalda, 2015; Hermon, 2015; Hermon, 2016; Hermon, 2017). Batang Hari River is one of the rivers on the island of Sumatera that flows in two provinces which are West Sumatera Province and Jambi Province. In the segment of West Sumatera Province, the Batang Hari River has 5 sub-watersheds which are Gumanti sub-watershed, Sangir sub-watershed, Jujuhan sub-watershed, Pangean sub-watershed and Batang Hari sub-watershed (Hermon, 2010; Hermon, 2012; Oktorie, 2017)

The Batang Hari watershed has a catchment area of 842,050 ha with a total length of the Batang Hari River of $775 \mathrm{~km}$. About $583 \mathrm{~km}$ of it are in Jambi Province and $192 \mathrm{~km}$ of it are in West Sumatera Province (Bapedalda, Regional Environmental Status of West Sumatera Province 2014. Aside from being a water source for rice fields through irrigation networks, the Batang Hari river is also used by the community as a means of transportation, inland fisheries and public bathing, washing, and toilet facilities (MCK), even Unlicensed Gold Mining (PETI) activity.

This PETI activity is usually carried out along the Batang Hari River starting from South Solok District to Dharmasraya District. Land clearing activities for the development of oil palm plantations are found and there are still forest encroachment activities, so the level of erosion due to the flow of surface 
water has caused sedimentation on the Batang Hari River body. The current Batang Hari River water condition is very alarming where the turbidity level is very high and the mercury $(\mathrm{Hg})$ level exceeds the threshold. In the Batang Hari River, especially in the location of Jorong Gasiang Nagari Lubuk Ulang Aling Selatan, Sangir Batang Hari Subdistrict, the high level of mercury $(\mathrm{Hg})$ is indicated to originate from gold mining activity located in Sangir Batang Hari Subdistrict.

The environmental impacts that occur in the study area due to the unlicensed gold mining activity are the damage of the right-left border of the river (Hermon, 2016; Oktorie, 2018), the damage of surrounding forest areas due to the use of mechanical equipment in the form of hundreds of excavators and the construction of mining workers barracks that reach thousands of workers, morphology changing of the river, silting of the river at a certain point and narrowing of the river body (Hermon, 2016; Hermon et al., 2017; Hermon et al., 2018; Kristian and Oktorie, 2018).

There was also a disturbance in boat/tempek traffic in river transport shipping lanes due to the occurrence of sedimentation and narrowing of the river which resulted in the diversion of the shipping lanes that formed the curve of the shipping lane (Hermon, 2014; Hermon et al., 2018; Hermon, 2019). The shipping lanes usually tend to be straight because each water transportation cannot make a twist. That is because the water transportation cannot do a slope of more than 5\%. An excessive slope will cause danger to ships and other river transportation facilities.

In addition, environmental roads around the mine were also damaged due to heavy equipment transportation that brought excavators as mining equipment. This is not permitted because it does not meet the class of roads in South Solok District. This road damage usually causes the distribution of daily needs to be disrupted, so that the availability of daily needs is less on the market. The lack of the daily needs availability has caused the selling price of some basic commodities to be expensive, which in turn has an impact on the decline in the community's purchasing power.

The description of the facts above shows that the Unlicensed Gold Mining (PETI) activity greatly affects the surrounding natural conditions. Many studies have also conducted research on the effect of PETI on the natural environment. However, no studies have been found that examine the influence of PETI on people's living conditions, especially in Nagari Gasing. In fact, the potential for social conflict is also worthy of being highlighted because of changes in the composition of the society after the existence of PETI. For this reason, this research raises the topic of research that focuses on the impact of PETI on the conditions of the socio-cultural and economic life of the local community.

\section{Method}

According to the level of explanation and type of data and analysis, the research on unlicensed gold mining (a case study in Jorong Gasing Nagari Lubuk Ulang Aling Selatan, Sangir Batang Hari Subdistrict, South Solok District) is included to descriptive qualitative research, which is a research that aims to describe a phenomenon based on the results of exploration. The research conducted seeks to examine carefully, systematically the actual empirical phenomena regarding the issues raised. The use of this qualitative method has advantages because the exploration of the problem under study is not only based on reports of an event or phenomenon but also examined with other relevant sources. This method also allows a more flexible, not too detailed approach, which is unusual in defining a concept, as well as giving possibilities for changes when found more basic, interesting, unique and meaningful facts in the field, according to Aziz (Bungin, 2003).

The types of data obtained are primary data and secondary data. Primary data is sourced from objects directly and visually and from the community's opinions. The total number of respondents is 20 people. While secondary data is sourced from the Monitoring Report of the Quality of the Batanghari River Water by the Bapedalda of West Sumatera Province, Sangir Batang Hari Subdistrict in Numbers. The primary data collection in this study was carried out directly through observation and interviews. The results of the observations are documented in the form of photographs while the results of the interviews are arranged in a systematic form for analysis. As for secondary data collection, literature studies and document studies are carried out in the Bapedalda of West Sumatera Province, South Solok District Government. To support the validity of this thesis, the primary data obtained will be examined first before being used in analysis needs. The data validity testing is carried out using the Triangulation method with data sources and 
or data collection methods. This triangulation method is carried out by cross-checking the phenomenon, the data, and the information using different sources and methods. Information from interviews with respondents as a source of data is confirmed by other sources such as documentation data and observations (Moleong, 2002).

With the triangulation method, the validity of the data is more guaranteed because in principle this qualitative research focuses on how to obtain factual data in accordance with the phenomena that occur. Thus, the results of data analysis can produce factual information in accordance with the objectives of the study. In checking the validity of the data, the technique used is triangulation technique. Triangulation is a technique for checking the validity of data that uses something else. In this study, triangulation is a technique of checking data that utilizes the use of resources. Triangulation with sources means comparing and checking the degree of trust in information obtained through time and different tools in qualitative research (Patton, 1987). That can be achieved by: comparing observational data with interviews and photos, comparing what people say in public with what is said personally, comparing what people say about the research situation with what they say all the time, and comparing the situation and perspective of a person with various opinions and views of people. In this type of qualitative research, the data processing does not have to be done after data is collected or data processing is complete. In this case, the temporary data is collected, and the existing data can be processed and the data analysis can also be done simultaneously. In analyzing the data, the researcher can return to the field to find additional data that is seemed necessary and process it again. Suryanto \& Bagong (2006) said that data processing in qualitative research is done by classifying or categorizing data based on several themes according to the focus of the research.

\section{Result and Discussion}

\section{Unlicensed Gold Mining Impacts to the Decline of Water Quality on the Batang Hari River}

The results of measuring the quality of the Batang Hari River in the area of the research object (Jorong Gasing Nagari Lubuk Ulang Aling Selatan, Sangir Batang Hari Subdistrict, South Solok District) were carried out in 4 (four) times a year in June, August, September and November. The key parameters analyzed in this study were the $\mathrm{pH}$, the Total Suspended Solid (TSS), the Dissolved Oxygen (DO), the Biological Oxygen Demand (BOD), the Chemical Oxygen Demand (COD) and the Hg. The results of Batang Hari River water quality can be seen in Figure 1, Figure 2, Figure 3, Figure 4, and Figure 5.

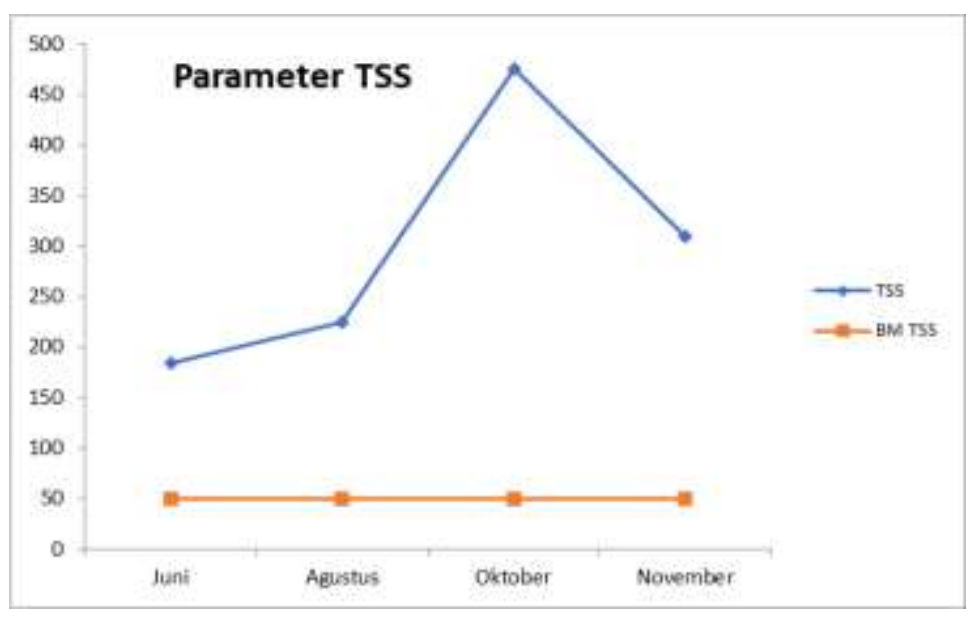

Figure 1. Graph of Water Quality for TSS Parameter 
ISSN: 2580-4030 (Print) 2580-1775 (Online)

Vol 3, No. 1, (pp. 54-61), June, 2019

http://sjdgge.ppj.unp.ac.id

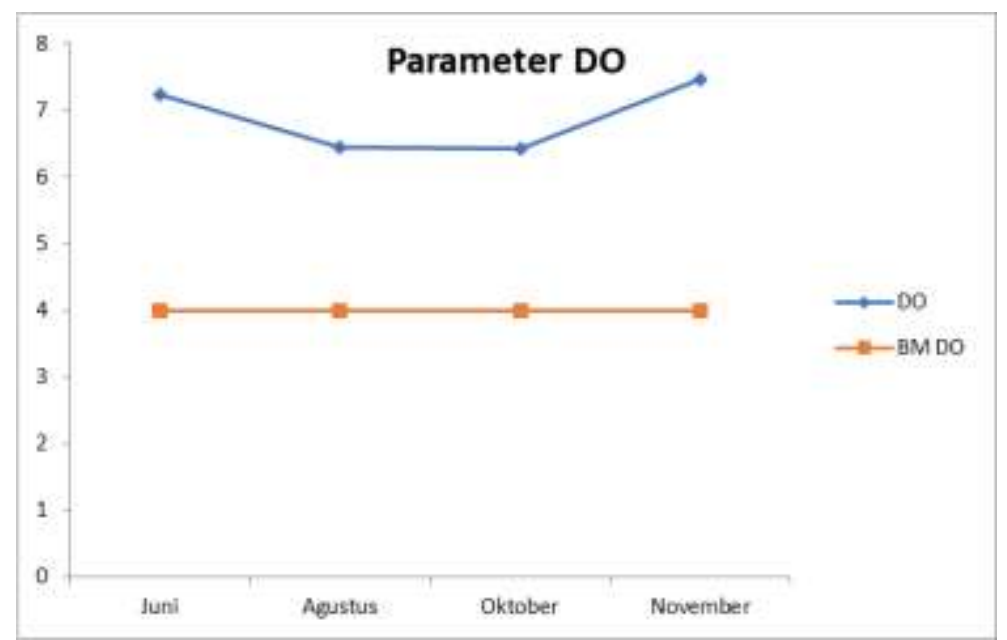

Figure 2. Graph of Water Quality for DO Parameter

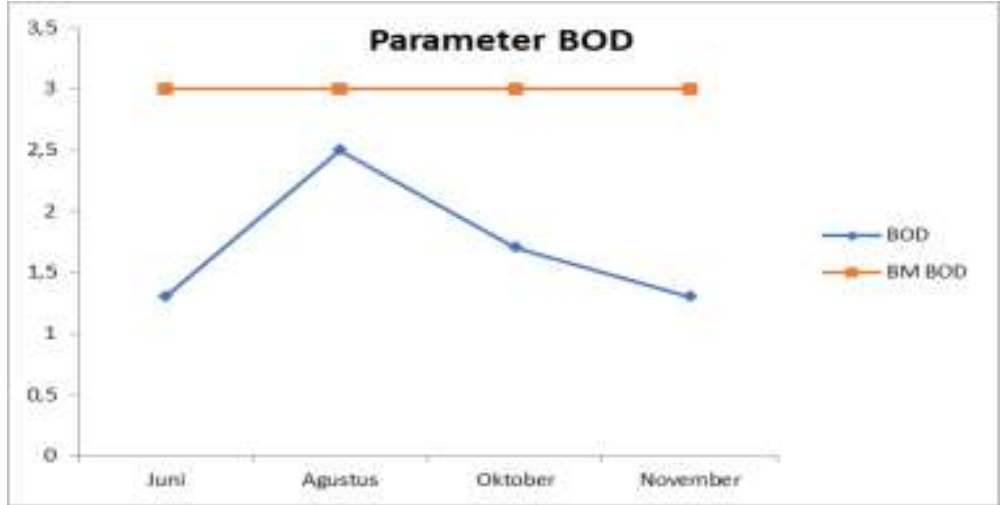

Figure 3. Graph of Water Quality for BOD Parameter

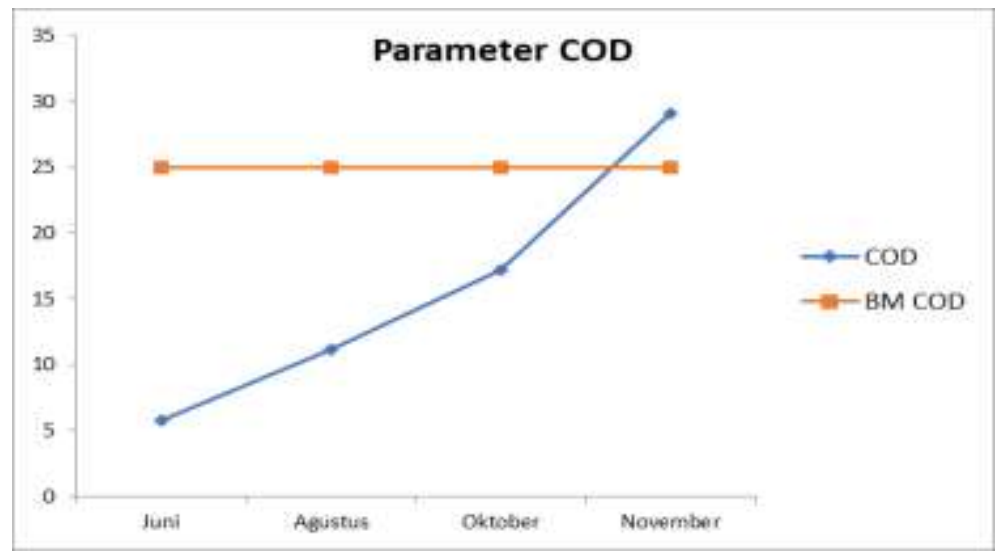

Figure 4. Graph of Water Quality for COD Parameter 


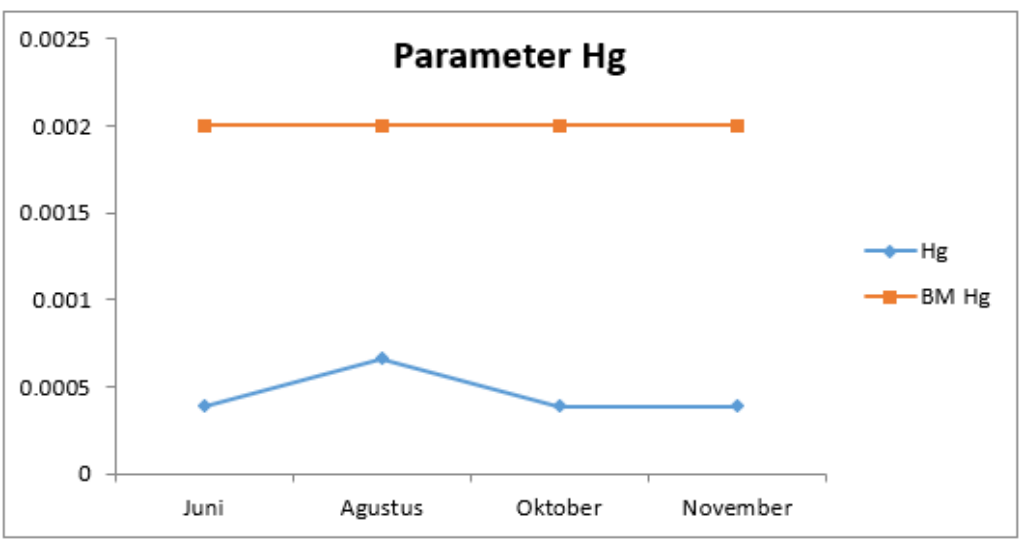

Figure 5. Graphic of Water Quality for Hg Parameter

Based on the graphs above and based on the Law Number 32 of 2009 concerning Protection and Management of the Environment in article 1 the general provisions that the entry or inclusion of living things, substances, energy and/or other components into the environment by human activities so as to exceed the standard prescribed environmental quality, it can be said that the Batang Hari River at the research site has been polluted, especially for TSS parameter. This is in line with the Government Regulation No. 82 of 2001 concerning Management of Water Quality and Water Pollution Control, that water pollution is the entry or inclusion of living things, substances, energy and/or other components into water and/or changes in water order by human activities or natural processes, so that the quality of water decreases to a certain level which causes water to become less or no longer functioning in accordance with its designation.

\section{The Changes of Land Trasnfer Function of Batang Hari River in Jorong Gasing Nagari Lubuk Ulang ALing Selatan}

Based on the results of monitoring of the Mining and Energy and Mineral Resources Office of South Solok District, the gold mining process in the Batang Hari River, especially Sangir Batang Hari Subdistrict, was done in a traditional manner (panning), using dompeng machines, lantern boats, excavator and dredgers. Based on the results of observations and direct interviews with residents and Environmental Management Agencies of South Solok District, the processed fiber satellite image data as attached map shows that there has been a change in the border rivers into gold mining activities without permits of $\pm 6.53 \mathrm{Ha}$ and $\pm 195 \mathrm{Ha}$ of area mining of PT. Geomenex at the research location. The damage to the Batang Hari watershed due to mining activities reached $22.54 \mathrm{Ha}$ based on the results of monitoring of the Bapedalda of West Sumatera Province in 2015.

The environmental impacts that occur in the study area due to unlicensed gold mining activities were damage to the right-left borders of the river, damage to surrounding forest areas due to the use of mechanical equipment in the form of hundreds of excavators and the construction of mining workers barracks that reach thousands of workers, morphology changes of the river, silting of the river at a certain point and narrowing of the river body. There was also a disruption of boat/tempek traffic in river transport shipping lanes due to the occurrence of sedimentation and narrowing of the river which resulted in the diversion of the shipping lanes that formed the twists and turns. The shipping channel usually tends to be straight because each water transport facility cannot make a twist and so the water transportation facilities cannot experience a slope of more than 5\%. An excessive slope will cause danger to ships and other river transportation facilities.

\section{The Impacts of PETI Activities on Socio-Cultural Life and Economy}

One of the social aspects examined in this study is about the utilization of the Batang Hari River by local residents, while the cultural aspects are examined from mutual cooperation activities and other 
customary practices. Gold mining activities do not disturb the economic activities or business of the residents. This was stated by most of the respondents reasoning that gold mining was one of their sources of income or livelihood. While other livelihoods come from rice fields/gardens/ ponds. If the residents do not have their own land, then the business is done by working on someone else's land. These residents will get income from a profit sharing system with the land owners.

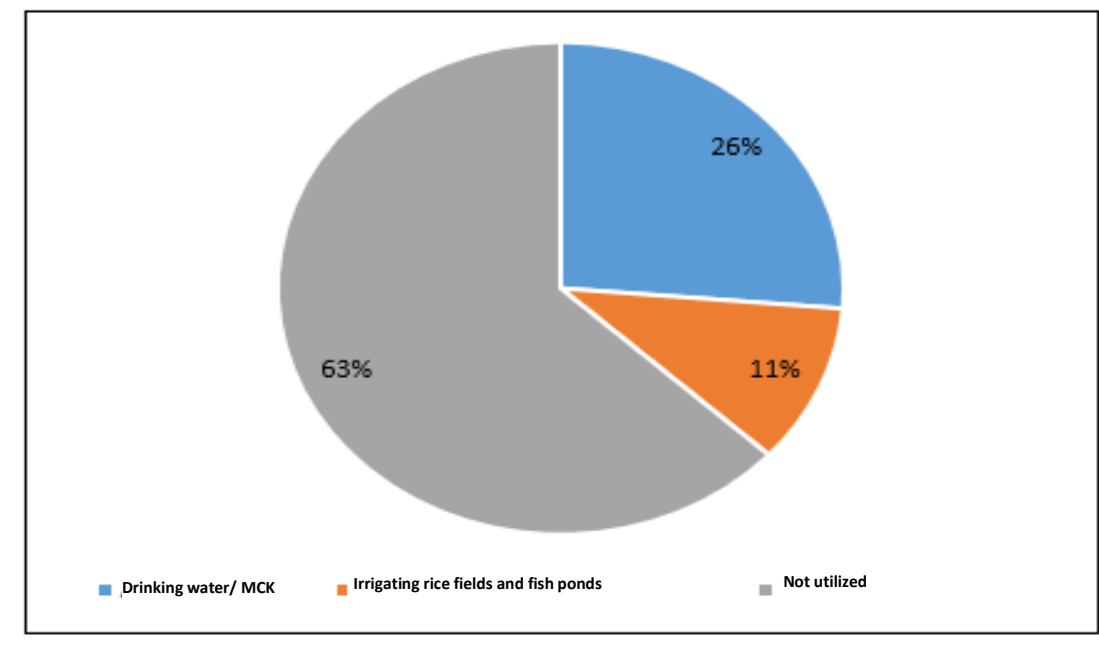

Figure 6. Diagram of The Water River Utilization

Based on the description above, the mining activities carried out by the community have undergone changes in the socio-economic life of the community in which the economic growth has increased and the pattern of social life has undergone a change. It is shown that the Jorong Gasing community who will shop at Pulau Punjung Market in Dharmasraya District or Padang Aro Market in South Solok District must carry around Rp. 5,000,000 while the Rp. 3,000,000 of it only goes to the people who are going to the market. This is in accordance with the opinion of Febriamansyah (2003) who stated that in a development effort, the need for a change in the socio-economic conditions of local communities is an unavoidable.

\section{Conclusion}

Based on the research that has been done, it can be concluded that there was a decrease in the quality of Batang Hari River, especially in the TSS parameter. There was also a change in the land transfer function around the research area that is designated for agricultural land/ fields/used as mining land. The river borders also experienced environmental damage caused by mining activities. The land utilization was not in accordance with the Regional Regulation of South Solok District Number 8 of 2012 dated December 2, 2012 concerning the RTRW of South Solok District in 2011-2031, in which the research location of Nagari Lubuk Ulang Aling Selatan, Sangir Batang Hari Subdistrict, South Solok District is a geological protected area in the area geological reserve. The economic income of workers and investors was found to be derived from mining activities, but the mining activities have indeed harmed the community around the watershed. The river water can no longer be used for daily needs and the community has difficulty with clean water. The socio-cultural conditions of the community seen from the knowledge and methods of mining have undergone changes in the pattern of mining carried out by previous ancestors. It is suggested to the next researcher to conduct research on $\mathrm{Hg}$ level in sediments in rivers and irrigation dams, $\mathrm{Hg}$ level in river animals, $\mathrm{Hg}$ level in paddy or rice in the lower reaches of PETI activities, and health problems in the surrounding communities. 


\section{References}

Bapedalda. 2014. Status Lingkungan Hidup Daerah Provinsi Sumatera Barat Tahun 2014. Padang: Bapedalda Provinsi Sumatera Barat.

Bapedalda. 2015. Status Lingkungan Hidup Daerah Provinsi Sumatera Barat Tahun 2015. Padang: Bapedalda Provinsi Sumatera Barat.

Bungin, B. 2003. Analisa Data Penelitian Kualitatif: Pemahaman Filosofis dan Metodologis ke Arah Penguasaan Model Aplikasi. Jakarta: Raja Grafindo Persada.

Febriamansyah, R. 2003. An Integrated Approach for Water Allocation in a Small River Basin. Dalam PhD Dissertation. Melbourne, Australia: The University of Melbourne.

Hermon, D. 2010. Geografi Lingkungan: Perubahan Lingkungan Global. UNP Press.

Hermon, D. 2012. Dinamika Cadangan Karbon Akibat Perubahan Tutupan Lahan Permukiman di Kota Padang Sumatera Barat. Forum Geografi: Indonesian Juornal of Spatial and Regional Analysis. Volume 26. Issue 1. p: 45-52. Uniiversitas Muhammadiyah Surakarta.

Hermon, D. 2012. Mitigasi Bencana Hidrometeorlogi: Banjir, Longsor, Degradasi Lahan, Ekologi, Kekeringan, dan Puting Beliung. UNP Press. Padang.

Hermon, D. 2014. Impacts of Land Cover Change on Climate Trend in Padang Indonesia. Indonesian Journal of Geography. Volume 46. Issue 2. p: 138-142. Fakultas Geografi Universitas Gajah Mada.

Hermon, D. 2015. Geografi Bencana Alam. Jakarta: PT RajaGrafindo Persada.

Hermon, D. 2016. Mitigasi Perubahan Iklim. Rajawali Pers (Radjagrafindo).

Hermon, D. 2016. Estimate of Changes in Carbon Stocks Based on Land Cover Changes in the Leuser Ecosystem Area (LEA) Indonesia. Forum Geografi. Volume 29. Issue 2. p: 188-196.

Hermon, D. 2016. The Change of Carbon Stocks and CO2 Emission as the Result of Land Cover Change for Tin Mining and Settlement in Belitung Island Indonesia.Journal of Geography and Earth Science. Volume 4. Issue 1. p: 17-30.

Hermon, D. 2016. The Strategic Model of Tsunami Based in Coastal Ecotourism Development at Mandeh Regions, West Sumatera, Indonesia.Journal of Environment and Earth Science. Volume 6.

Hermon, D. 2017. Climate Change Mitigation. Rajawali Pers (Radjagrafindo).

Hermon, D., P. Iskarni., O. Oktorie and R. Wilis. 2017. The Model of Land Cover Change into Settlement Area and Tin Mining and its Affecting Factors in Belitung Island, Indonesia. Journal of Environment and Earth Science. Volume 7 No. 6. p: 32-39. IISTE.

Hermon, D., Ganefri., A. Putra and O. Oktorie. 2018. The Model of Mangrove Land Cover Change for the Estimation of Blue Carbon Stock Change in Belitung Island-Indonesia. International Journal of Applied Environmental Sciences. Volume 13. Issue 2. p: 191-202. Research India Publication.

Hermon, D., A. Putra and O. Oktorie. 2018. Suitability Evaluation of Space Utilization Based on Enviromental Sustainability at The Coastal Area of Bungus Bay in Padang City, Indonesia. International Journal of GEOMATE. Volume 14. Issue 41. p: 193-202. Geomate International Society.

Hermon, D. 2019. Evaluation of Physical Development of The Coastal Tourism Regions on Tsunami Potentially Zones in Pariaman City-Indonesia. International Journal of GEOMATE. Volume 17. Issue 59. p: 189-196. Geomate International Society.

Hermon, D., Ganefri, Erianjoni, I. Dewata, P. Iskarni and Alexander Syam. 2019. A Policy Model of Adaptation Mitigation and Social Risks The Volcano Eruption Disaster of Sinabung in Karo Regency-Indonesia. International Journal of GEOMATE. Volume 17. Issue 60. p: 190-196. Geomate International Society.

Kristian, A and O. Oktorie. 2018. Study of Coastal Mangrove Conservation in the World. Sumatra Journal of Disaster, Geography and Geography Education. Volume 2. Issue 1. p: 49-52

Moleong, L. 2002. Metodologi Penelitian Kualitatif. Bandung: PT. Remaja Rosdakarya. 
Oktorie, O. 2017. A Study of Landslide Areas Mitigation and Adaptation in Palupuah Subdistrict, Agam Regency, West Sumatra Province, Indonesia. Sumatra Journal of Disaster, Geography and Geography Education. Volume 1. Issue. 1. p: 43-49. Master Program of Geography Education.

Oktorie, O. 2018. Model Kebijakan Responsif Pemulihan Bencana Letusan Gunung Sinabung. Jurnal Kapita Selekta Geografi. Volume 1. Issue 1. p: 15-20

Patton, M. Q. 1987. Qualitative Education Methods. Beverly Hills: Sage Publication.

Suryanto and Bagong, S. 2006. Metode Penelitian Sosial Berbagai Alternatif Pendekatan. Jakarta: Prenada Media Group 